\title{
6 Hannah Arendt and Michel Foucault on Biopolitics, Time and Totalitarianism
}

Although Hannah Arendt never used the term 'biopolitics', she has developed some of the most critical insights into the primacy of life in modern society and the reduction of people to mere living things in $20^{\text {th }}$-century totalitarianism. These insights, I will argue, essentially refer to a structure of temporality which I will term processual temporality, that runs from the beginnings of modernity through $20^{\text {th }}$ century totalitarianism up to post-war capitalist mass society. I will show that Arendt's examination of modern temporality to large degrees overlaps with Michel Foucault's diagnosis of modern biopolitics. Unlike Foucault, however, Arendt also offers a starting point for developing a different, non-biopolitical conception of politics, based on a non-processual form of temporality: the temporality of the interval.

Recent work in philosophy and the social sciences has highlighted a number of intersections and affinities between Foucault and Arendt, although they never referred to one another (Allen 2002; Gordon 2002b). Both reject an essentialist conception of human nature and a teleological conception of history, be it of Hegelian or Marxist provenance, and both share a commitment, although spelled out differently, to a type of inquiry that combines philosophical and historical perspectives. It would not be too far-fetched to say that not only Foucault but also Arendt reconstructed the 'history of the present', to use Foucault's term. Both investigate the ideational dimension of history without reducing it to a traditional history of ideas. While in Foucault it is the body that is of particular importance to his history of the present, in Arendt it is the category of experience. It has also been noted that both Arendt and Foucault move beyond a Weberian notion of power (Allen 2002; Gordon 2002b), both stressing the relational and performative, and, as I would add, the generative character of power. However, one must not take the analogy too far because, as Richard Dana Villa (1992) remarks, when Foucault and Arendt speak 
about power, they speak about different things. While the Foucauldian concept of power in a specifically crypto-normative way denotes a ubiquitous, pervasive, and somewhat dark and troubling force, power in Arendt (1970) emanates from concerted political action. Power, in Arendt, is the public and visible manifestation of human action's 'weak' messianic potency, making its appearance in a specifically messianic structure of temporality: the interval.

It was Giorgio Agamben, who most influentially highlighted the aspect of biopolitics in Arendt and Foucault, bringing together the Foucauldian concept of biopolitics with Arendt's analysis of totalitarianism. In his Homo Sacer, Agamben (1998), who makes detailed reference to Arendt's analysis of how totalitarianism reduces persons to mere specimens, deplores the fact that Arendt did not explicitly draw a connection between her analysis of modern society in The Human Condition (1958) and her analysis of totalitarianism in Origins (1968). He concludes that Origins was altogether without a biopolitical perspective (Agamben 1998) whereas Foucault, he holds, has never dealt with $20^{\text {th }}$-century totalitarianism. Both statements are only partly correct. Foucault, in the last part of The History of Sexuality (1980) and in his lectures at the Collège de France in 1976 (Foucault 2003), albeit briefly, did refer to totalitarianism, and these passages, as Alan Milchman and Alan Rosenberg (1998) have shown, are perfectly in line with his other works. As far as Arendt is concerned, it is correct that in Origins she does not refer to the terms 'life' or 'biopolitics' and does not explicitly explain the relation between The Human Condition and Origins. However, in The Human Condition, she intensively examines the notion of life in connection with the emergence of the social and the decline of politics in occidental history up to the $20^{\text {th }}$ century. Strangely enough, Agamben makes little or no use of these thoughts. In this chapter, I will not undertake a detailed discussion of Agamben's political theory but rather continue the project of bringing Arendt and Foucault together on the issue of biopolitics. Although the term 'biopolitics' does not appear in Arendt, I will argue that in her work we can find a rich and in-depth analysis of the specific features that constitute modern biopolitics, so that we can read Arendt as a theorist of biopolitics avant la lèttre. So far, this aspect in Arendt's work seems to have been widely overlooked. An exception is André Duarte (2005) who argues that reading Origins and The Human Condition as analyses of biopolitical violence, even though biopolitics is not an Arendtian category, enables us to find the missing link between these two works and to understand the lingering continuity between capitalist market society and totalitarian violence in our contemporary world. Duarte suggests that we live in a world in which 
there is a constant danger that the Arendtian animal laborans gets converted into the Agambian homo sacer. My own reading of Arendt widely corresponds to this thesis, but I will discuss in more detail the overlaps and intersections between Foucault's conception of biopolitics and Arendt's analysis of totalitarianism. These intersections, I argue, concern the analysis of certain critical features of the modern project that culminate and converge in totalitarianism: the zoefication of humans, a technocratic understanding of politics, and, not least, modern processual temporality. The issue of temporality, as I will show, is of particular significance in Arendt's political thought. Furthermore, I will focus on Arendt's specific contribution to a theory of biopolitics and modernity and point out the additional insights she can offer. Those consist, in my view, first in opening up an additional dimension of understanding in regard to biopolitics, one that refers to a debatable but also inspiring existentialist, if not theological, layer in her thought. Second, and linked to this dimension, with her concept of natality, she presents an alternative way of conceiving temporality, politics, and life that has the potential to take us beyond the spell of biopolitics.

\subsection{Life and Labor}

Both Arendt and Foucault belong to those thinkers who draw our attention to the dark sides of the modern project. What Jeffrey Isaac said about Arendt is equally true for Foucault: both are puzzled by the irony "that the modern age, which proclaims the value of life above all else, is also the age of genocidal mass murder" (Isaac 1996, 65). That is, both Arendt and Foucault ask the question of how the atrocities of $20^{\text {th }}$-century totalitarianism were rooted in the soil of modernity and how to unearth these roots. Whereas Arendt provides an in-depth study on the functioning principles of totalitarian rule and the nexus between shaping, regulating, and enhancing the Volkskörper and classifying and killing people marked as 'life not worth living', Foucault's works, as Milchman and Rosenberg (1998) point out, rather shed light on the formative stages of this nexus. Milchman and Rosenberg argue that the idea of life not worth living can be seen as one possible, though not necessary, outcome of the practices of classifying and categorizing in terms of health-disease, normal-pathological, fit-unfit, which Foucault traced back to the emergence of modern medicine, psychiatry, biology and the carceral society. In the following, I will highlight some further aspects in Foucault's and Arendt's work that 
illuminate the threads running from the formation of the modern project to the extermination camps. To avoid misunderstandings, this is not to say that Nazism was the inevitable, necessary outcome of anything. It is only to say that Nazism was able to build on ideational and practical elements that were and are still key to modernity and that it is worthwhile studying these elements in order to be aware of the possibility that they might again grow into a real nightmare.

The first aspect I want to highlight is the observation of what might be termed the political zoefication of humans. ${ }^{1}$ Looking at the formative stage of the modern state, Foucault observes that it was accompanied or even characterized by the move through which humans as living beings became the subject and target of political rule:

Power would no longer be dealing simply with legal subjects over whom the ultimate domination was death, but with living beings, and the mastery it would be able to exercise over them would have to be applied at the level of life itself; it was the taking charge of life, more than the threat of death, that gave power its access event to the body" (Foucault 1980, 142f.).

The life at stake here is not so much the life people live, the life story, the biography, but rather the zoe-aspect of their existence. Public policy and the welfare state through the late $18^{\text {th }}$ and $19^{\text {th }}$ centuries, Foucault argues, coemerged with practices, institutions, and new bodies of knowledge, designed to take care of the physical aspects of human life such as fertility, health, disease, longevity, or morbidity, in order to enhance the productivity of the population as well as its loyalty to the state (Foucault 1988). Foucault makes it clear that the shift towards the population was a decisive precondition for the emergence of the economy as a separate sphere which he links to the governmentalization of the state (Foucault 2000a, 220), that is, the understanding of politics as government in the sense of management.

This analysis partly overlaps with Arendt's indictment in The Human Condition that modern society is being based on labor rather than on work or political action. Labor, in her terminology, means the type of activity that serves the necessities of life and the ongoing circle of consumption and reproduction.

Agamben (1998) has pointed out that the Greeks had no single word for life but the two terms bios and zoe. Unlike the contemporary use of the prefix bio in terms such as biology or biopolitics, bios denoted the life one was living whereas zoe comprised the physical aspects of being an animal, a living thing. 
The purpose of labor is not really to produce lasting works but to maintain the life processes of the individual, society, and the species. The Arendtian categories of labor, work, and action are certainly problematic, as Bronislaw Szerszynski (2005) argues, particularly when understood as universal, neatly separable features of human existence or as an account of the social evolution. Still, I think, if we do not share Arendt's "phenomenological essentialism" (Benhabib 1996, 123ff.) but rather understand labor, work and action as a typology of action within modern society, these concepts may be useful to understand some of its basic features.

From this perspective, Arendt's delineation of the role of labor as compared with work and action clearly draws from Marx's analysis of capitalist accumulation (Braun 2001); human activity merely serves as a means to feed the ongoing dynamic of a process that Marx has analyzed as the process of capitalist accumulation. Any act of work tends to get transformed into an act of labor insofar as it is neither performed for its own sake nor for the sake of creating a lasting product but merely as a means to maintain the dynamic of the economy. Arendt speaks of "repetition and the endlessness of the process itself" and of a "specifically modern acceleration", which has transformed work into labor (Arendt 1958, 125). It is not least in this sense that life in modern society has become the highest good; however, it is not the life of human individuals but rather the 'life' of society, the ongoing dynamic of the economic process, which ranks as the supreme good.

Thus, while Foucault stresses that life is a resource which gets mobilized, Arendt points out that life is constantly (re)produced. Both state that individual life functions as a force that feeds into the dynamic of a larger process, be it as a resource or as a product, and that the newly emerging sphere of the social is not least characterized by the constant consumption of life in order to maintain the dynamic of this process. They both make the diagnosis, similar to the Marxian analysis of capitalist society, that the rise of the social implies a certain degradation of individual lives to mere means of sustaining and feeding the economy. Thus, to a certain extent, we can say that the political zoefication of humans is inherent in modern society from the very beginning.

The totalitarian systems of the $20^{\text {th }}$ century have taken the political zoefication of humans to the extreme in reducing certain groups of people to the status of being mere life. They did so through stripping these people of their civil rights, social positions and political status. The concentration camps, Arendt says, demonstrated "that human beings can be transformed into spec- 
imens of the human animal" (Arendt 1968, 455). She also makes clear, that the practice of stripping people of their legal and political status was not invented by the Nazis. It had already occurred in the aftermath of the First World War, when hundreds of thousands of people became refugees, homeless or stateless due to expatriation, flight, or expulsion. These people, Arendt says, belonged "to the human race in much the same way as animals belong to a specific animal species" (Arendt 1968, 302); they were reduced to a status similar to that of an animal; it did not matter what they thought or did but only what they were (Arendt 1981). While it was the Nazi state that declared whole categories of people to be 'life not worth living' and accordingly destroyed their lives, the Stalinist Soviet Union also, as both Arendt and Foucault remark, classified political adversaries in biological terms, as mentally ill (Foucault 2003) or "dying classes or parasitic races" (Arendt 1996, 938). ${ }^{2}$

\subsection{Total Management}

The political zoefication of humans is closely linked to another thread which, according to both Arendt and Foucault, runs through modern politics and society up to totalitarianism: the conception of politics as administration, namely the administration of life. Foucault (2003) shows that the emergence of biopolitics comes with a shift from understanding politics basically as the continuation of war to an understanding of politics as administrating, regulating, calculating, and managing the life of the population. Within this new paradigm the population was seen as a resource that can be mobilized in order to strengthen the state. Administrating and managing this resource was dependent on knowledge and gave rise to population statistics, population science, hygiene, public health, or eugenics. These bodies of knowledge were, as Foucault points out, intrinsically based on a logic of classifying, qualifying, categorizing, and ranking. Biopolitics in Foucault, as Larry Reynolds (2005) notes, actually means bio-administration. Foucault thus diagnoses a specifically technocratic understanding of politics in modernity: politics is mainly the set of technologies required to achieve certain ends such as the increase

2 I refer to the German version here since the German version of Origins, which has not so much been translated but rather rewritten by Arendt herself, is much sharper and stronger compared to the earlier English version. Whenever I refer to the German version, it is for this reason. 
of the welfare and productivity of the population and the relative strength of the state as compared to other states.

Arendt, too, views modern politics mainly as administrating or managing the necessities of life. The $19^{\text {th }}$ and $20^{\text {th }}$ centuries, according to her, have developed an understanding of politics that equates politics with government and sees it as a sort of housekeeping. Whereas Foucault takes a non-normative view, simply stating the substitution of one unappealing understanding of politics for another, Arendt takes a decisively normative perspective, mourning the loss of the public sphere and referring to an emphatic idea of politics as an activity that forms an end in itself.

Again, we find that a general feature of modernity culminates in totalitarianism. Under totalitarian rule, there is no room for politics in the sense of expressing and debating different viewpoints and opinions and for acting in concert as opposed to exercizing command and obedience. In short, there is no space for political action as an end in itself. The sites where the utmost destruction of the ability for political action altogether took place were the camps. Hence, we find that both Arendt and Foucault see totalitarianism as the extreme case of a system that has turned politics into a knowledge-based administration of life.

In totalitarianism, according to Arendt, this knowledge-based administration of life takes on a new dimension: she depicts the system of the camps in terms of experiments and laboratories, that is, in terms of techno-scientific knowledge production. Totalitarianism, here, is seen as a gigantic experiment on human subjects, the camps being the laboratories where new technologies of turning humans into mere life are developed and tested: "The concentration and extermination camps of totalitarian regimes serve as the laboratories in which the fundamental belief of totalitarianism that everything is possible is being verified" (Arendt 1968, 437).

\subsection{Politics, Life and Modern Temporality}

The last observation about the relation between modernity and totalitarianism in Foucault and Arendt concerns the processual structure of time. It is here that Arendt can offer some crucial insights into the nature of totalitarianism and the modern link between politics and life. Therefore, in the following, I will reconstruct her argumentation in more detail. 
Again, Foucault makes us aware of a specifically new modern feature of power and politics which, as Arendt's analysis makes clear, fully and fatally takes shape in totalitarianism. He points out that the new modern form of power which refers to 'man-as-a-living-being (Foucault 2003, 242) does not really target individuals as living beings. It does not primarily operate through exercizing direct control over the body or through intervening in individual lives. Instead, it targets collective phenomena such as the birth rate, or the average life expectancy. While on the individual level these phenomena seem ungovernable, they are not necessarily so when taken as collective phenomena. This, however, implies another characteristic new feature of biopolitics, namely that it targets processes, temporal phenomena, phenomena which

occur over a period of time, which have to be studied over a certain period of time: they are serial phenomena. The phenomena addressed by biopolitics are, essentially, aleatory events that occur within a population that exists over a period of time (Foucault 2003, 246, emph. added).

Biopolitics is essentially about "taking control of life and the biological processes of man-as-species" (Foucault 2003, 247, emph. added); it "is a technology in which bodies are replaced by general biological processes" (Foucault 2003, 249). In other words, the processes Foucault is talking about do not take place within an individual's life time. On the contrary, they pass through individual life. The individual's birth and death do not delimitate but on the contrary mediate and facilitate the activities of modern governing. Hence, the life that biopolitics targets has a supra-individual dimension, not just in a numeric but also in a temporal sense (Gerodetti 2005). Modern politics, as Foucault depicts it, consists of a set of government technologies which act upon a target, the biological processes in the population, within which individual life is just a transitory moment.

We will rediscover this relation between politics and life and its specific temporal structure in a radicalized form in Arendt's analysis of totalitarianism. To her, it forms a key to understanding the specific nature of totalitarianism. Understanding, here, means to recognize the principle that sets this form of government in motion (Arendt 2005). However, it is also more:

Insofar as totalitarian movements have sprung up in the non-totalitarian world (crystallizing elements found in that world, since totalitarian governments have not been imported from the moon), the process of understand- 
ing is clearly, and perhaps primarily, also a process of self-understanding (Arendt 2005, 310).

Trying to understand totalitarianism, for her, includes asking the question of how it could have an appeal to people and she examines this question both in her works on totalitarianism and in The Human Condition. However, she does so not on a political sociology plane but on a speculative, if not theological, plane, seeking to understand the rule of processual temporality as an answer to the questions of death, finitude, and loneliness. It is at this point that Arendt and Foucault definitely part; Foucault would not concede that it made sense to deal with questions of that kind. He deliberately restricts himself to the study of when and how certain questions emerged and evolved. However, such selfrestriction comes at a cost: Within these limits it is neither possible to ask the question of appeal, which certainly limits the range of understanding what was going on, nor is it possible to develop better, non-destructive answers or to distinguish between bad, worse, and better answers at all. Therefore, I think it is worthwhile to take a closer look at Arendt's analysis of the configuration of politics, life, and temporality that characterizes the nature of totalitarianism and links it to the modern predicament. Against this backdrop we can then reconstruct Arendt's concept of natality as a guidepost to break away from this still dangerous configuration.

At the core of totalitarianism, both as a form of government and as a type of ideology, Arendt argues, lies the idea that all human action is subordinated to laws of nature or laws of history. In retrospect, she sees one such line leading from Darwin to Nazi racism, another from Marx to Stalinism. What both have in common is the idea "that a superior process of movement has seized both nature and history" (Arendt 1996, 952). Totalitarianism, according to Arendt, is largely about executing the laws of nature or history. What does this mean? It essentially implies a disastrously distorted, preposterous relation between continuity and change, intransience and transience, timelessness and time. Here, Arendt in fact starts from some basic assumptions about human needs, and about the kind of relation between intransience and transience that would be more appropriate to humans. Her assumption is that, due to their capacity for freedom and spontaneity, human actions and their results unavoidably have a moment of unpredictability, instability, and transience to them. That is, transience is built into the human condition-which is a problem that men inevitably have to deal with. Positive law and political institutions, to Arendt, form something like an appropriate compensatory 
answer to this problem. They are able to provide continuity and stability in order to balance the essential instability and changeability of human action. Positive laws are depicted in terms of boundaries or a "framework of stability" (Arendt 2005, 341), which confines but also permits and protects the exercise of freedom. As such, positive law hedges what she calls a "common world, the reality of some transcending continuity" (Arendt 2005, 342).

Two other salient concepts in this context are home and homelessness. Arendt goes so far as to assume that "human beings need the constant transformation of chaotic and accidental conditions into a man-made pattern of relative consistency" (Arendt 1968, 352). The transformation of class society into mass society and the related process of atomization, in her view, have eroded such a common world and left the masses in a condition of "essential homelessness" (Arendt 1968, 352). She even speaks of a "social and spiritual homelessness" (Arendt 1968, 352, emph. added), which underlines that she is arguing on a highly speculative plane here.

The totalitarian response to this spiritual homelessness was to twist around the relation between continuity and change so that under totalitarian rule it is human action which is made static (Arendt 2005, 342), whereas all laws are turned into laws of movement. Terror, the main instrument of totalitarian rule, stabilizes or freezes men (Arendt 1968, 342) through shutting down the spaces where freedom and spontaneity could be exercized, whereas the laws of nature or history undermine and ultimately destroy the conditions of stability and a common world. At first glance, the laws of nature or history, in contrast to positive, man-made law, seem to be characterized by their unchanging, permanent quality, their timeless presence, as Arendt puts it. At the same time, however, the laws of nature or history display an inherent dynamic linked to the political zoefication of humans. We can reconstruct Arendt's argument through discerning three ways in which the laws of nature or history form laws of movement: first, they allegedly determine the course and movement of history, much as natural laws determine the course of the planets. Second, totalitarian movements make them their highest-ranking source of authority, so they become the laws of these movements. Third, the totalitarian movement as such can only proceed if it avoids the establishment of any stable institutional order. In order to maintain its existence, it has to preserve its form as a political movement even after having taken seizure of the state. Arendt insists that totalitarianism is far from forming a monolithic or hierarchical state structure but is rather characterized by its shapelessness (Arendt 1968, 395). Through mechanisms such as the confusing co-existence 
of party and state offices, real and façade power centres, overlapping and competing jurisdictions, and not least the constant shifting of the centre of power, it avoids the establishment of stability. Keep in mind, Arendt insists, that the goal of a totalitarian movement is not simply to retain power within the territorial boundaries of a state but to conquer the world and to create a new mankind. The latter in particular can be seen as a dynamic goal. Whereas world conquest could theoretically be achieved-the surface of the earth is limited-this is not the case with creating the master race or the 'new man'; these are endless projects requiring an ongoing process of purge and elimination. It is here that the different dimensions of the laws of movement converge with one another and with the political zoefication of humans: the project of creating the new human species through the execution of suprahuman laws of movement, thereby avoiding stabilization and preserving the political movement as such, according to Arendt, forms the essence of totalitarianism.

\subsection{Improving Life}

Creating the new mankind, or the new human race or species, through executing the laws of nature or history displays and implies the general features that Foucault ascribes to biopolitics: It targets collective and serial, temporal phenomena. Put differently, it operates on the level of the species and employs the sequence of generations, thereby transgressing, utilizing, and mobilizing individual life. Further, when Foucault highlights evolutionism as a general paradigm that emerged in the $19^{\text {th }}$ century he comes very close to Arendt's analysis of processual thought:

Basically, evolutionism, understood in the broad sense-or in other words, not so much Darwin's theory itself as a set, a bundle, of notions (such as: the hierarchy of species that grow from a common evolutionary tree, the struggle for existence among species, the selection that eliminates the less fit)—naturally became within a few years during the nineteenth century not simply a way of transcribing a political discourse into biological terms, and not simply a way of dressing up a political discourse in scientific clothing, but a real way of thinking about the relations between colonization, the necessity for wars, criminality, the phenomena of madness and mental illness, 
the history of societies with their different classes, and so on. (Foucault 2003 , 256f.)

Evolutionism, according to Foucault, forms an important link between classical biopolitics and what he calls the evolutionary racism developed by Stalinism and Nazism. Thus, Foucault, too, points at the specifically processual structure of modern temporality, which links the biopolitical dimension of the modern project to the totalitarian project. ${ }^{3}$ Totalitarianism prolongs and radicalizes the features of biopolitics highlighted in Foucault to the point that it uses the elimination of humans as a means of productively consuming individual life in the production process of the new species life. The only functions individuals can have vis-à-vis the laws of movement are to execute them and/or to become "walking embodiments of these laws" (Arendt 2005, 340), which is by no means mutually exclusive. Executing them means actively applying the standards according to which certain individuals or groups do or do not allow for the unfolding dynamic of the laws of movements. Embodying them means being classified according to these standards. Laws or processes which function through transgressing and productively consuming individual lives are not served through compliance but through providing the material in which they realize themselves. This material can be of higher or lower quality and the political zoefication of humans is the outcome of a mechanism that judges the existence of individuals or groups according to the question of whether they present suitable or unsuitable material to realize and promote the project of enhancing the human race. Within this logic, being deemed a 'dying' or a 'decadent class' functions much the same way as being deemed 'unfit to live', whether the classification refers to physical qualities or not.

Compared with $19^{\text {th }}$-century processual thought, the totalitarianism as depicted in Arendt thus adds, or at least dramatically increases, the element of acceleration. The totalitarian project is not only about scientifically understanding the laws of movement but about actively promoting the process of their unfolding. Here, execution is at the same time acceleration. Its instrument is terror, which makes terror the borderline case of a technocratic, instrumentalist understanding of politics. Hence, Arendt seems to say, processual thought had a certain appeal to the masses in their spiritual homelessness between different regimes of time and forms of power in Foucault see Portschy (2019). 
because it enabled them to participate in a permanent, intransient, timeless presence. The alleged intransience or permanence of these laws, however, was a fatal error because in fact their operating principle was mobilization, dynamization, acceleration. What processual temporality really did was destroy the chance of establishing some sort of this-worldly stability, continuity, or common home. In the end, the

supra-gigantic forces whose movements race through humanity, dragging every individual willy-nilly with them-either riding atop their triumphant car or crushed under its wheels-may be various and complicated: still, it is surprising to see how, for all practical political purposes, these ideologies always result in the same 'law' of elimination of individuals for the sake of the process or progress of the species. From the elimination of harmful or superfluous individuals, the result of natural or historical movement rises like the phoenix from its own ashes; but unlike the fabulous bird, this mankind which is the end and at the same time the embodiment of the movement of either History or Nature requires permanent sacrifices, the permanent elimination of hostile or parasitic or unhealthy classes or races in order to enter upon its bloody eternity. (Arendt 2005, 341)

The kind of eternity the totalitarian movement has to offer is a deadly eternity, the permanence it produces is the "tranquility of the cemetery" (Arendt 2005,348 ). Hence, the totalitarian project is based on a specifically processual structure of temporality in which endlessness has taken a double meaning: first, the processes determined by the laws of nature or history and executed through terror cannot come to an end because their goal, the production of a new human species, can never be completed. Second, each individual and each human activity merely counts as a means to promote the process and not as an end in itself. These processes have a direction, but no end(s). To Arendt, this structure is expressed concisely by the maxim of the SS: "No task exists for its own sake" (Arendt 1968, 409). This attitude, she says, destroys "all genuine interest in specific jobs and produces a mentality which sees every conceivable action as an instrument for something entirely different" (Arendt 1968, 409).

Here, however, we also see that processual temporality is not confined to the totalitarian project, although it is within the totalitarian project that it assumes its most deadly power. Rather, the relation cited earlier between actions and ends bears considerable resemblance to Marx's analysis of the relation between exchange value and utility value under capitalist conditions, 
in which human productivity is essentially transformed into a mere means to advance the process of accumulation. Indeed, Arendt's later work on modern society can, arguably, be read as a study on the functioning of processual temporality before and after totalitarianism. In The Human Condition, as I will point out in the following, Arendt both makes an endeavor to understand the development of processual temporality and to present an alternative model, the temporality of the interval, the former crystallizing in the priority of life, the latter in the concept of natality.

\subsection{Living in the Interval}

In The Human Condition, Arendt explores the rise of 'life' to be the supreme good in occidental culture; she shows how the changing notion of 'life' is related to a pertinent transformation of temporality and how these transformations form responses to certain fundamental, traumatic historic experiences. The polis, in her view, had offered its citizens a kind of "worldly immortality" in that it formed the institutional framework for the possibility of remembrance (Arendt 1958, 314). Life was conceived of as a life story that can be passed down over generations and remembrance constitutes a response to human mortality. This response required a body politic though with a functioning context of narration and remembrance. The decline of the polis therefore meant a traumatic experience and the cultural response to that experience was the invention of a new form of temporality, namely eternity, which came with a revaluation of the vita contemplativa in relation to political action. This shift, however, came at the price of devaluating the only human capacity that is able to create a common world before death.

Similarly, Arendt understands Christianity and its idea of the immortal soul as a response to the decline of the Roman Empire. However, this shift meant a further devaluation of political action and the political realm insofar as the immortality of the soul did not rely on a functioning body politic. On the contrary, in order to save one's soul and attain immortality, what mattered was to turn away from worldly political life. For this reason, Arendt argues, the price for this new form of immortality was alienation from the interpersonal world.

The beginning of the modern age and the development of modern science mark a further upheaval in that science implied a model of investigation that devalued contemplation as a path to truth so that contemplation lost 
the status of being the most highly regarded form of life. For a short time, Arendt says, work took the place of contemplation and homo faber the place of the philosopher. However, to the extent that religion lost its capacity to determine the appropriate ends of work it lost its significance and was superseded by processual thought, be it evolutionism, historical materialism, life philosophy, or the belief in progress, as a new notion of temporality. This notion of temporality in turn, she argues, is modelled on the biological life process, or on a biologistical understanding of life. In terms of bios and zoe, it would be modelled on zoe, referring to the idea of an entity that, in analogy to the species, sustains itself through the coming and going of individuals. The species in that sense is beyond life and death and so is the assumed entity that underlies processual thought, be it termed nature, history, society, or progress.

However, we could also say that Arendt understands processual thought as a response to the 'spiritual homelessness' that has accompanied the inhabitants of the western world from the turn to metaphysics in ancient Greece to post-war capitalism. To model thought on the life process-zoe-therefore means a specifically immanentist endeavor of constructing immortality. Note, however, that Arendt does not consider the quest for immortality to be an essential feature of 'human nature'. In her interpretation, the quest for immortality is not a cause but rather an outcome of or a response to another human need, which she does assume to be essential: the need to find a home in the world, to be respected as a member of this worldly community.

Incidentally, according to Arendt, the capitalist economy of the $20^{\text {th }}$ century is in no way based on work but on labor in that every human activity is directed at the maintenance of the economic dynamic. Again, we find, "no task exists for its own sake"; no activity forms an end in itself, anything and any activity merely serves to feed the automatically proceeding dynamic. From this perspective, we still live under the rule of processual temporality. It certainly does not take as murderous a shape as it has taken in Nazism and Stalinism insofar as it is not directed at the production of one new single mankind and does not use terror as its main instrument. However, to the extent that human activities are qualified and treated as mere means to feed an automatic, relentlessly proceeding paramount process, whether it is named progress or globalization, we are still under the spell of processual thought. In post-war society, Arendt says, one form the rule of supra-human processes takes is the inexorable progress of science and technology "compelling us to do whatever we can, regardless of consequences" (Arendt 1970, 86), not least in the realm 
of biotechnology which, in Arendt's view, is apparently driven by the desire to escape the human condition of natality and mortality.

\subsection{Beyond Biopolitics: Zur Welt Kommen}

Hence, we note that Arendt and Foucault help us discern certain critical, interrelated elements of the modern project that fatally culminated and converged in the totalitarian projects of the $20^{\text {th }}$ century, but did not disappear with them. As such features we have identified the political zoefication of humans, a technocratic understanding of politics, and processual temporality. Biopolitics can be understood as the combination of these elements. As long as these elements are to be found in contemporary thought, science, technology, society, or politics, it is advisable to watch out for their impact and their possible convergence. Arendt, in my view, goes a little further than Foucault in that she decidedly outlines an alternative, non-biopolitical understanding of politics, life and temporality captured by the concept of natality. The idea of natality is meant to present a different and better response to the existential human need to find a home in the world. This response would differ from the various predominant responses we can find in occidental history which all focused on overcoming mortality. Up to now, the history of occidental thought has been preoccupied by mortality (Arendt 1958). Metaphysics, Christianity, and processual thought, in this perspective, do respond to the need of finding a home in the world and to the experience of this need being frustrated. Metaphysics and Christianity responded in developing a specific temporal form: eternity, a sphere of permanence and intransience beyond the interpersonal world and superior to it. In processual thought, however, eternity moves from transcendence into the immanence of nature or history and in this move gets dynamized so that what remains from eternity is just the constancy of the process. Processuality is the new temporal form emerging in the $19^{\text {th }}$ century. Hence, to Arendt, both eternity and processuality form temporal structures that respond to the problem of homelessness in the world, a problem caused by the nature of human action itself, but they respond in a way which rather makes things worse as they devaluate and undermine those human faculties through which humans are able to create a home in this world. To focus on natality instead of mortality would mean to acknowledge that the only remedy to the volatility of human action and its results is human action itself, complemented by the capacity to promise and to forgive. While human ac- 
tion produces results that are volatile and unstable, action is also the capacity to begin anew, to create a new political community in concert with others. Arendt concludes Origins with the warning that totalitarianism will stay with us as an ever-present potentiality but also with the more optimistic outlook that the end of totalitarianism at the same time implies the promise of a new beginning: "Beginning, before it becomes a historical event, is the supreme capacity of man, politically, it is identical with man's freedom" (Arendt 1968, 479).

Although the concept of beginning, initium, is taken from Augustine, Arendt gives it a distinctive turn in linking it to the factum of birth: "This beginning is guaranteed by each new birth; it is indeed every man" (Arendt 1968, 479). In The Human Condition, she develops this idea further by coining the concept of natality to capture the linkage between beginning, freedom, and action. Being born—zur Welt kommen in German-is not just a physiological event at the beginning of life, although it is that too, but in the case of humans it also means entering the world which is already inhabited by others. For Arendt, it is the beginning of a being that is capable of beginning. Action can be understood as a kind of second birth, through which a person, again, enters the world of interactions and common projects. Unlike many other metaphors of a second birth this one does not devaluate the first birth. The second birth is not the antithesis of the first but its confirmation; it means accepting the gift of spontaneity and freedom man has received already at and through birth. While birth forms the beginning of physiological life that has to be sustained through labor and work, action is the essence of political life. Physiological life thus provides time for the good life; action fills zoe with bios. It is important to note though that political life, in Arendt, is no idyll, no paradise that had been lost and could be regained; the idea of embracing natality is not meant to lead us back to an alleged state of static timelessness. There is no denying that human action can cause mistakes and that political institutions are volatile, which is why we need promising and forgiving.

With the help of forgiveness one cannot undo mistakes caused by human action but one can prevent them from determining the future. By means of making and keeping promises human beings can bring consistency and commitment into their affairs without relinquishing their freedom. Focusing on natality, instead of mortality, means appreciating these human capacities and sustaining the institutional framework that allows them to be exercized. To focus on natality also means to break away from eternity and processuality and to introduce a new temporal form instead: the interval. Thus, it is not 
least a revision of our understanding of time that the concept of natality is aiming at, as Julia Kristeva (2001) has remarked. ${ }^{4}$ Human life, then, is not understood as a transitory stage to eternity or as a means to feed the dynamic of an ongoing process nor as a timeless idyll but as "the time interval between birth and death" (Arendt 1958, 97). As such it has a beginning and an end, it is limited, and it provides time for the good life, which in turn can be remembered as a life story.

To focus on natality would thus mean putting an end to processual temporality and replacing it with the time of the interval. It is here where we can locate what Susannah Young-ah Gottlieb has called Arendt's weak or inconspicuous messianism (Gottlieb 2003, 160). Arendt frequently refers to the figure of Jesus, particularly when she wants to emphasize the significance of action and forgiveness. Jesus, she holds, was far from preaching the superiority of contemplation over action: "The only activity Jesus of Nazareth recommends in his preachings is action, and the only human capacity he stresses is the capacity 'to perform miracles"' (Arendt 1958, 318).

Hence, it is not necessarily Jesus who has messianic qualities but rather Jesus demonstrates the messianic, potentially redeeming powers of action and forgiveness. To Arendt, these amount to the human faculty to perform miracles. In many passages of the New Testament, she tells us,

miracles are clearly not supernatural events but only what all miracles, those performed by men no less than those performed by a divine agent, always must be, namely, interruptions of some natural series of events, of some automatic process, in whose context they constitute the wholly unexpected (Arendt 1968/1993, 168).

This miraculous power of human action has a messianic quality to it as it ends one time and opens up another; it disrupts the time of the process and opens up the time of the interval. It brings the current time to a close insofar as it stops the racing of time towards the future and breaks open a time span in the present, a time between limits.

The element of messianism and the thought of redemption are alien to Foucault and it is with regard to this messianic perspective that Arendt's and of life in The Human Condition. Kristeva does not sort out the different meanings of the term life in this book. 
Foucault's conceptions of temporality fundamentally diverge. Foucault's considerations about time do not refer to the messianic idea of an end of time, whereas Arendt's conception of human action as a messianic power that manifests itself in the public sphere bears strong affinities to what Gershom Scholem identifies as the messianic idea in Judaism:

Judaism, in all of its forms and manifestations, has always maintained a concept of redemption as an event which takes place publicly, on the stage of history and within the community. It is an occurrence which takes place in the visible world and which cannot be conceived apart from such a visible appearance (Scholem 1971, 1).

Arendt, as well as Foucault, strictly rejects the strong messianic idea that the world could be saved once and for all, which she, as well as Foucault, considers extremely dangerous. Nevertheless, she does convey a messianic message, only that the messianic powers, the human faculties of action and forgiving, are themselves temporal; they operate within time, their results are unstable and all they can do is open up time for a new beginning in this world. Hence, messianic time in Arendt has the structure of the interval, redemption means freedom, the exercise of which in Arendt is synonymous with power, and such power takes place, quite as Scholem put it, publicly, in the community.

To Foucault, in contrast, freedom means the capacity to think differently and to conceive of ourselves differently, different from the requirements of subjectification, of becoming an autonomous subject through confessing and truth telling and thereby producing knowledge required for the biopolitical management of the living. The liberty Foucault finally leaves us with consists of thought practices and self practices; liberty to Foucault is "an attitude, an ethos, a philosophical life" (Foucault 1997, 319), "a permanent critique of our historical era" (Foucault 1997, 312), a "critical ontology of ourselves", it is "work carried out by ourselves upon ourselves" (Foucault 1997, 316). It is a liberty that remains preoccupied with the self, if not confined within the limits of the vita contemplativa. Foucault's way of interrogating history and exposing allegedly universal, necessary, rational or emancipatory features of modernity as being not only historical but also inherently ambiguous provides us with a tremendously helpful prerequisite to analyze the logic of modern biopolitics. It is hard to see, however, how this self-centred, philosophical conception of liberty could point at an alternative conception of politics, one that enables us not only to analyze but also to overcome biopolitics. 
The concept of natality, I have argued, takes us a step further, offering an alternative understanding of politics, life, and temporality. Human life here is understood not as a moment in an endlessly racing process whose laws are to be executed on the individual, nor as a manageable entity but as the time span between birth and death. Time is not the medium for the execution of supra-human processes but the interval that provides the chance to perform activities for their own sake. Politics, finally, would be understood not as the management of populations or the acceleration of economic or scientific progress ${ }^{5}$ but as acting in concert together with others, and the purpose of politics would not be to enhance the quality of some collective entity, to create a better species or to maintain the dynamics of the economy, but to make the world a home.

5 Arendt's critique of the idea of progress and processual thought clearly draws from Walter Benjamin's Theses on the Concept of History (1968). The affinities and differences between Arendt's and Benjamin's conception of temporality would, however, require another study. For exploring the use of Benjamin for a critical analysis of biopolitics see Wehling 2019. 